\title{
Patent Applications on Representative Sectors of Biotechnology in Brazil: an Analysis of the Last Decade*
}

\author{
Liliana Mendes', Beatriz Amorim-Borher ${ }^{2}$, Celso Lage ${ }^{3}$
}

\begin{abstract}
The present article aims to assess the innovative activity in the Brazilian most representative sector in biotechnology field. The search was conducted through patent applications of residents at the National Institute of Industrial Property (INPI - Brazil), from 2000 to 20I0. This article will also examine the patent applicants' profile and the partnerships among academic institutions and private firms in Brazil. The website of European Patent Office (EPO) patent database - Espacenet was used to conduct the survey, and the search strategy fields selected for the patent applications were: (i) Priority Number: BR (Brazil), and (ii) the International Patent Classification (IPC) - CI2N, C07KI4, and C07H2I/04. The patent applications by Brazilian residents, from 2000 to 2010 in the Espacenet for the classifications adopted indicates a total of 396 patent applications in the most representative sectors in biotechnology over the past 10 years. After the Brazilian Innovation Law there is a growth trend line particularly in the years 2007 and 2008 . The universities hold $48 \%$ of the patent applications in biotechnology, following by Individuals/ Researchers with 20\%, Public Research Centers and Private Firms with $15 \%$, and $11 \%$ of the total, respectively.
\end{abstract}

Keywords: Patents; innovation; biotechnology; university, intellectual property, and Brazil.

\footnotetext{
* The opinions expressed in this article are the sole responsibility of the authors.

1,3Intellectual Property Academy (ACAD), National Institute of Industrial Property (INPI). Rua Mayrink Veiga, $n^{\circ} 9-$ Centro - Rio de janeiro / RJ - Cep: 20090-9I0, Brazil.Tel. +55-2I-3037-4046. E-mail: 'liliana@inpi.gov.br.

${ }^{2}$ Brazil Office of World Intellectual Property Organization (WIPO). Rua Farme de Amoedo 56, $7^{\circ}$ andar - Ipanema -

Rio de Janeiro / RJ - CEP: 22420-020, Brazil.
}

ISSN: 07I 8-2724. (http://www.jotmi.org)

Journal of Technology Management \& Innovation (C) Universidad Alberto Hurtado, Facultad de Economía y Negocios. 


\section{Introduction}

Economic globalization forced countries to seek for competitiveness by promoting technological innovation. Several governments have been eager to facilitate the consolidation of national firms at the same time that they establish incentives and favorable conditions to attract foreign investment. In 2004, Brazil launched the Brazilian Innovation Law aiming at strengthening the transfer of knowledge from academic environment to the private sector. This law has impacted the management of knowledge in many sectors, especially in those where science is closer to technology, for instance, Information and Communication Technology (ICTs) and Biotechnology, therefore has foster partnership for innovation and patent applications.

Innovation has been defined by Lundvall (2005) as a process that involves the discontinuity of technical features in the use of a product or process, and the introduction, diffusion and adaptation of a new technology. The author points out that it is important to distinguish the concept of innovation and the concept of invention. Invention is the creation of something new that can be disclosed by scientific papers, patents, prototypes, even if it still does not have a commercial application. Innovation is the invention that hits the market. The author puts emphasis on the existence of empirical studies showing that the key to the transformation of technological innovation into economic results would be the training and capacity building in human resources.

Evaluating around 2,000 significant technological innovations in Britain from 1945 to 1979, Pavitt (1990) proposes a taxonomy of sectorial technological innovation patterns and establishes three patterns groups with distinct technological paths: (i) "suppliers dominated firms": they are in traditional sectors such as agriculture, civil construction and equipment industry whose technological path is defined by cost reduction; (ii) "production intensive firms": they are based on large-scale fabrication and assembly production. The firms produce for price-sensitive consumers. This group comprises food products, metal manufacturing, shipbuilding, motor vehicles, and glass and cement; and (iii) "science-based firms": in this case, the main sources of technology are the R\&D activities, based on the development of the underlying sciences in the universities. They are in the chemical and the electronic/electrical sectors. Although the author does not refer to biotechnology since in the surveyed period there was no industry characterized as such, modern biotechnology is currently acknowledged as science-based industry.

A study conducted by Rapini (2007) states that sectors such as genetic engineering, organic and inorganic chemistry, food technology, biotechnology, laser technology and microelectronics (telecommunications, electronic components, data processing), mainly characterized for being science-based, are more prone to the University-Enterprise interaction.

These authors understand the importance of the protection mechanisms of intellectual property (IP), with emphasis on patent mechanism, to secure the investments made in the innovative process, mainly in Research \& Development (R\&D) activities. For Pavitt (op. cit.), patent protection is especially important to the science-based industries in view of the high investments in R\&D as the patents ensure the temporaryexclusive right to exploitation of innovation allowing the investment return to their inventors. Modern biotechnology is basic knowledge-intensive field, requiring a great deal of basic research and a long development process for creating a new product. The cost to bring the product to market is high, thus there is a claim for IP Rights.

From the 1980s, the so-called "modern biotechnology" defined as the use of biological processes, living organisms or their parts (tissues and cells) for generation of products or industrial process, with large-scale industrial application of scientific and technological advances. The innovation in products and process is the result of biological science research development.

In the last few years, many relevant events have happened in the field of biotechnology. Figure $\mathrm{I}$ is an incomplete attempt to show a list of those events in the history of modern biotechnology.

Biotechnology industries has played a special role in technological innovation in many countries, particularly those who are on the technological frontier. But developing countries also are very concerned about this. Besides de Innovation Law, Brazil has invested in human resources qualification, and has launched several postgraduate courses at universities, including biotechnology area. Until $201 \mathrm{I}$ there were 30 postgraduate courses in biotechnology in Brazil.

One important aspect to evaluate the performance of the country in innovation is the number of patent applications, as well as investments in R\&D.These indicators have been used as an indicator of technological innovation development and of the of firms, regions and countries. The number of patent applications can reflect its technological dynamism and the information contained in the patent document can give some indications on the direction of technological changes.

Jannuzi and Souza (2008) shows an increase, 150 percent, in patent applications by Brazilian universities at the United States Patent and Marks Office (USPTO), from 88 patent applications in 1990, to 220 in 2000. Póvoa (2006) analyzed de patent application by Brazilian universities at National Institute of Industrial Property (INPI), for 25 years (1979 
to 2004), and has shown that 47,2 percent of them were applied in the last 3 years (2002, 2003,and 2004). Other studies has showed the same significant increase in patent application at large, and in particularly at universities (Gullo, et al., 20I I; Oliveira and Velho, 2009; Souza, et al., 20I I; Vasconcellos, 2003).

Furthermore, Querido, et al. (20I I) has surveyed both, patent application and patent granted at Brazilian universities. These authors have created a Index of Patents Granting to reflect de university efficiency in innovation process.
The present article aims to assess the innovative activity in the most representative areas in biotechnology through patent applications of residents at the National Institute of Industrial Property (INPI - Brazil), from 2000 to 20I0. At first it presents a short overview of innovation in Brazil. Then there is a description of the search methodology process and strategy. And finally the article presents the main findings, by examining the patent applicants' profile and the tendencies of partnerships among academic institutions and private firms in this field in the Brazilian context, as well.

\begin{tabular}{|c|c|}
\hline Year & Event \\
\hline 1971 & Escherichia coli recombinant DNA (USA) \\
\hline 1972 & Chakrabarty patent application (USA) \\
\hline 1973 & Recombinant DNA technology discovered in the USA \\
\hline 1974 & $\begin{array}{l}\text { Embrapa creates Cenargen (National Center for } \\
\text { Genetic Resources) (Brazil) }\end{array}$ \\
\hline 1976 & 1st biotech company in the world - Genentech (USA) \\
\hline 1978 & DNA segment responsible for insulin was isolated and inserted into E. Coli Bacterium (USA) \\
\hline 1980 & Interferon is produced with recombinant DNA technology (USA) \\
\hline 1981 & Chakrabarty patent was granted (USA) \\
\hline 1982 & USA approve the use of recombinant insulin \\
\hline 1982 & National Program of Biotechnology in Brazil is launched ( $\mathrm{PRONAB/CNPq)}$ \\
\hline 1986 & Creation of the Brazilian Association of Biotech Enterprises (ABRAPI) with 8 enterprises \\
\hline 1987 & HR Training Program for Strategic Activities (RHAE) at MCT/ Brazil \\
\hline 1990 & 1765 patent applications at USPTO (USA) \\
\hline 1990 & 32 patent applications at INPI (Brazil) \\
\hline 1990 & The beginning of the Human Genome Project (HGP) in the USA \\
\hline 1994 & Trade Related Intellectual Property Aspects Agreement (TRIPS) launched by OMC \\
\hline 1996 & The Brazilian IP Law launched \\
\hline 1997 & Beginning of the sequencing of the bacterium Xylella fastidiosa (FAPESP / Brazil) \\
\hline 2000 & Completion of HGP in the USA (1st phase - "DNA draft") \\
\hline 2000 & $\begin{array}{l}\text { Biotechnology and Genetic Resources Project - Genome Brazil / } 29 \text { patent applications (TECPAR / } \\
\text { Brazil) }\end{array}$ \\
\hline 2001 & $\begin{array}{l}4284 \text { biotech companies worldwide and US } \$ 35 \text { billion revenue; } \\
\text { in Brazil - } 304 \text { biotechnology-based companies }\end{array}$ \\
\hline 2001 & Creation of Biotechnology Sectoral Fund (FINEP / Brazil) \\
\hline 2002 & 7763 patent applications at USPTO \\
\hline 2003 & The final mapping of the human genome (USA) \\
\hline 2005 & Brazillian Innovation Law is launched \\
\hline 2012 & 30 postgraduate programs in Biotechnology (Brazil) \\
\hline 2013 & U.S. Supreme Court ruled that human genes can not be patented \\
\hline
\end{tabular}

Figure I - Chronology of some relevant events in biotechnology

ISSN: 07 I8-2724. (http://www.jotmi.org)

Journal of Technology Management \& Innovation @ Universidad Alberto Hurtado, Facultad de Economía y Negocios. 


\section{The Innovation in Brazil: a brief overview}

In 2010, a daily Brazilian newspaper published a reportage announced a very important achievement: Brazil rose four positions in the world ranking and became the 13th biggest science producer in the world, with 26,482 scientific articles published in indexed journals in 2008 , according to a UNESCO Report. Despite the evolution of the research, the reportage signals problems in transforming research conducted in universities into innovation in firms, as it is shown by the low number of patent applications in the country. Thus, Brazil is quite good in R\&D investments, but is not able to transform these investments into technological innovations. Moreover, $80 \%$ of the country's scientists and engineers are in the universities or research centers which are almost always public institutions, while in the United States (USA) $80 \%$ of the engineers are in the private firms. (Cruz and Pacheco, 2004).

For the Brazilian Minister of Science, Technology and Innovation, what is currently lacking is a bridge to connect universities to private sector, since "we occupy relevant places in the world scientific production (...). Of the overall published scientific articles $2.5 \%$ are produced by Brazilians" (Agência Gestão C,T\&I, 20I2). According to the Minister, very few sectors have achieved a good technology and innovation development in Brazil. Aeronautics, oil and agriculture were the sectors that had participation from research, development and innovation institutions, accordingo to him.

The number of patent applications has been used as an indicator of technological development. According to the Oslo Manual (1997), the number of patents of a particular company or country can reflect its technological dynamism. However, the Oslo Manual also identifies problems related to the use of patents as indicators, "because many innovations do not correspond to patented inventions; many patents were inventions of technological and economic value almost irrelevant; although many of them have quite expressive value, many others will never result in innovation." (op.cit., p. 27)

Still, patent applications continues to be used as an indicator of innovation. Therefore the analysis of the European Patent Office (EPO) Patent Database - Espacenet, that is used in this search, makes it possible to identify the situation of patent application in biotechnology in recent years in Brazil.

Futhermore, the Brazilian Innovation Law launched in 2004, and implemented in 2005 plays a relevant role in the promotion of innovation and scientific-technological research. It aims to foster the interaction between the private sector and the academic institutions to strengthen the competitiveness of the national industrial sector. In this regard, it provides innovation incentives and has between others objectives, the one to strengthen a culture of innovation, and intellectual property in the context of science and technology institutions that has launched the Centers for Technological Innovation (Núcleos de Inovação Tecnológica - NITs) at the universities and public research centers.

There is already a process of improving the regulatory framework for innovation. The proposed Amendment to the Constitution - "Innovation PEC", as it became known, for example formalizes the National System of Science, Technology and Innovation, which will coordinate the actions of public and private entities and foster collaboration by allowing sharing of human resources and equipment. Also, there is Law Project 2.177/20II, which provides the preparation of the National Code of Science, Technology and Innovation. Among the points of the new law, are creating research cooperative environments, and flexible exclusive dedication of researchers linked to public institutions.

In this context, national and international regulatory framework have been stimulating stronger competitiveness among countries. Hence, they exert pressure to transform research into innovation. In addition, in the international level, the TRIPS Agreement has introduced a new standard for protection of IP Rights. In the knowledge-based economy, the ability to generate and diffuse innovations has a direct relationship with levels of productivity and competitiveness achieved by countries. This context has required a new field of knowledge to understand what intangible assets are, and its economic importance. In this sense, this scenario has showed how relevant is to study the innovation process at the universities and how they are appropriating the knowledge generated in their research centers in biotechnology field.

\section{The survey on Biotechnology Patent Applications: Methodology}

The website of EPO patent data base Espacenet were used to conduct the survey on patent applications. According to the website, it offers free access to more than 70 million patent documents worldwide, containing information about inventions and technical developments from 1836 to today.

The Espacenet database provides information about patent applications of more than 90 countries and is characterized as a fairly complete and updated public database with more search options available. In addition it has free access and a friendly interface.

The search strategy used, i.e. the search fields selected at Worldwide Collection of Published Applications (http:// worldwide.espacenet.com/advancedSearch?locale=en_EP), in item "Advanced Search", were: 
- $\quad$ Priority Number: "BR” (Brazil) “AND” Year (the years were enter one by one from 2000 to 20I0); and

- IPC (International Patent Classification): “CI2N”, "C07K I4" and "C07H2 I/04" (one by one).

Thus, the three classifications adopted cover the most current information in representatives areas of biotechnology. They are defined as follow:

- $\quad$ CI2N - Microorganisms or enzymes; and their composition (biocides, pest repellents or attractants, or plant growth regulators containing microorganisms, viruses, microbial fungi, enzymes, fermented, or substances produced by, or extracted from, micro-organisms or animal material);

- $\quad$ C07KI4 - Peptides having more than 20 amino acids; Gastrins; Somatostatins; Melanotropins (Melanocytestimulating hormone); Derivatives thereof:This subclass will contain patents in proteomics (any patented protein);

- $\quad \mathrm{C07H2l/04} \mathrm{-} \mathrm{Compounds} \mathrm{containing} \mathrm{two} \mathrm{or}$ more mononucleotide measures, having separate phosphate or polyphosphate groups, linked by saccharide radicals of nucleoside groups, e.g., nucleic acids with deoxyribozyme as radical saccharide: DNA patents. They contain the overall genomics.

The International Patent Classification (IPC) was implemented after the Strasbourg Agreement, and entered into force in 1975. It is a global index for the broader technological fields, and establishes a single and international classification for patents. Today over 100 countries use this classification, including Brazil.The IPC has been periodically revised in order to improve the system and to take account of technical development. In the IPC technologies are hierarchically ordered in accordance to the degree of generality.

This search does not attempt to cover what is understood by biotechnology at the conceptual point of view. Instead it aims to be a cutting from the representative areas of the biotechnology sector. For instance, Santos (2010) proposes 15 different classifications for biotechnology, while the present survey proposes only three. However, the classifications proposed by the author cover a broad spectrum, comprehending new plant varieties and health, bioremediation, enzymes, even equipment.

For the search of this article we considered that new plant varieties obtained by traditional breeding are not part of modern biotechnology. If the new variety is obtained by genetic engineering, then it will receive the CI $2 \mathrm{~N} I 5$ classification and it will be detected by the classification proposed here. Another example, if a new strain of yeast for alcoholic fermentation is developed, this patent applications will also be classified as $\mathrm{CI} 2 \mathrm{~N}$, but if only the temperature system is modified, the patent applications shall not be considered. With this delimitation we aim to identify only those patent applications that develop new biotechnological technologies. Therefore, conventional vaccines, for example, will not be computed, but the recombinant will. New varieties of plants will be left out if classic improvement was used since this type of improvement does not enter modern biotechnology. In the same way, if genetic engineering was used in production process it will be included in one of the three classifications applied.

Even the Organisation for Economic Co-Operation and Development (OECD, 2005, p.5) presented a report "to outline a statistical framework to guide the measurement of biotechnology activity" that shows 30 IPC codes for provisional definition of biotechnology patents. However, it indicates that $55.5 \%$ of EPO biotechnology patent applications was attributable to $\mathrm{CI} 2 \mathrm{~N}$ alone.

So to better define the classifications to be used in a patent search, one must take into account the objective delimitation of what is sought, effectively.This particular study works with the data on modern biotechnology defined previously in this article. These three IPC codes, CI2N, C07KI4, and C07K2I/04, will allow a comprehensive search in modern biotechnology most representatives sectors.

After the search strategy definition, all summaries of the patent applications in those IPC codes were ordered by year. From this material, it was possible to draw up a summary table for each year, containing the patent applicant, the abstract of the patent applications, and the patent applicants' profile. This reference framework made it possible to identify repetitions, and incomplete or incorrect data that were checked in the complete document for each patent applications. Data tabulation was performed taking into account the following variables:

- Number of patent applications per year;

- $\quad$ Number of patent applications by applicants' profile (universities, individuals, research centers, private companies and partnerships);

- $\quad$ Percentage of participation by applicant profile; and

- $\quad$ Historical series from year 2000 to 2010.

The survey on Biotechnology Patent Applications: Main Results

The assessment of the main results of the survey conducted on the patent applications by Brazilian residents, from 2000 
to 2010 in the Espacenet Patent Database for the classifications adopted $(\mathrm{CI} 2 \mathrm{~N}, \mathrm{C} 07 \mathrm{~K} / 4$, and $\mathrm{C} 072 \mathrm{I} / 04)$ indicates a total of 396 patent applications over the past 10 years, as shown in Table I.

The figures should be correct to eliminate errors, i.e., remove cases of non-residents (patent applications that are not from Brazil); of patent applications in previous years; and duplicated document. This happens because the patent publication may be incomplete, and Espacenet is unable to identify the applications properly. The corrected figures is $30 \%$ less then the total shown by Espacenet. As Brazilian

\begin{tabular}{|l|r|r|}
\hline Year & $\begin{array}{c}\text { Patent Applica- } \\
\text { tions } \\
\text { Espacenet Total }\end{array}$ & $\begin{array}{c}\text { Patent Applica- } \\
\text { tions of Brazil- } \\
\text { ian Residents }\end{array}$ \\
\hline 2000 & 45 & 31 \\
\hline 2001 & 36 & 14 \\
\hline 2002 & 29 & 21 \\
\hline 2003 & 47 & 29 \\
\hline 2004 & 53 & 36 \\
\hline 2005 & 45 & 34 \\
\hline 2006 & 50 & 37 \\
\hline 2007 & 79 & 70 \\
\hline 2008 & 72 & 55 \\
\hline 2009 & 51 & 37 \\
\hline 2010 & 40 & 32 \\
\hline total & 547 & 396 \\
\hline
\end{tabular}

Table I - Number of patent applications of residents in Brazil (2000 to 2010) patent applications are low, this makes a significant difference. Thereby the corrected figures were the one that were used by this search. Graphs I shows the number of patent applications per year along the decade. Note a growth trend line caused mainly by the large number of applications in the years 2007 and 2008.

It is possible to conduct an analysis of the content of the patent application filed in biotechnology in the classifications selected in order to know the technological fields that are being searched by Brazilian inventors. So far it is likely to identify "genetic engineering" as the most of patent applications.

\section{Patent Applicants' Profile}

In order to classify the various types of patent applicants and their respective profiles, it was adopted five categories:

a) Universities: this category comprises higher education institutions, buy their own or in partnership. They develop scientific research, and may be public or private entities This survey focus in this patent applicant category;

b) Individuals: they are researchers or inventors who conduct patent filing as individuals, and this category may comprise only one individual or a group of researchers;

c) Research Centers: they are mostly public. The exception is Brazilian Petroleum Company (Petrobrás). This company has a management model similar to public research centers as: Brazilian Agro Business Company (EMPRAPA); Brazilian Nuclear Energy Commission (CNEN); Brazilian National Council for Research (CNPq), Butantan Institute, and Oswaldo Cruz Foundation (FIOCRUZ);

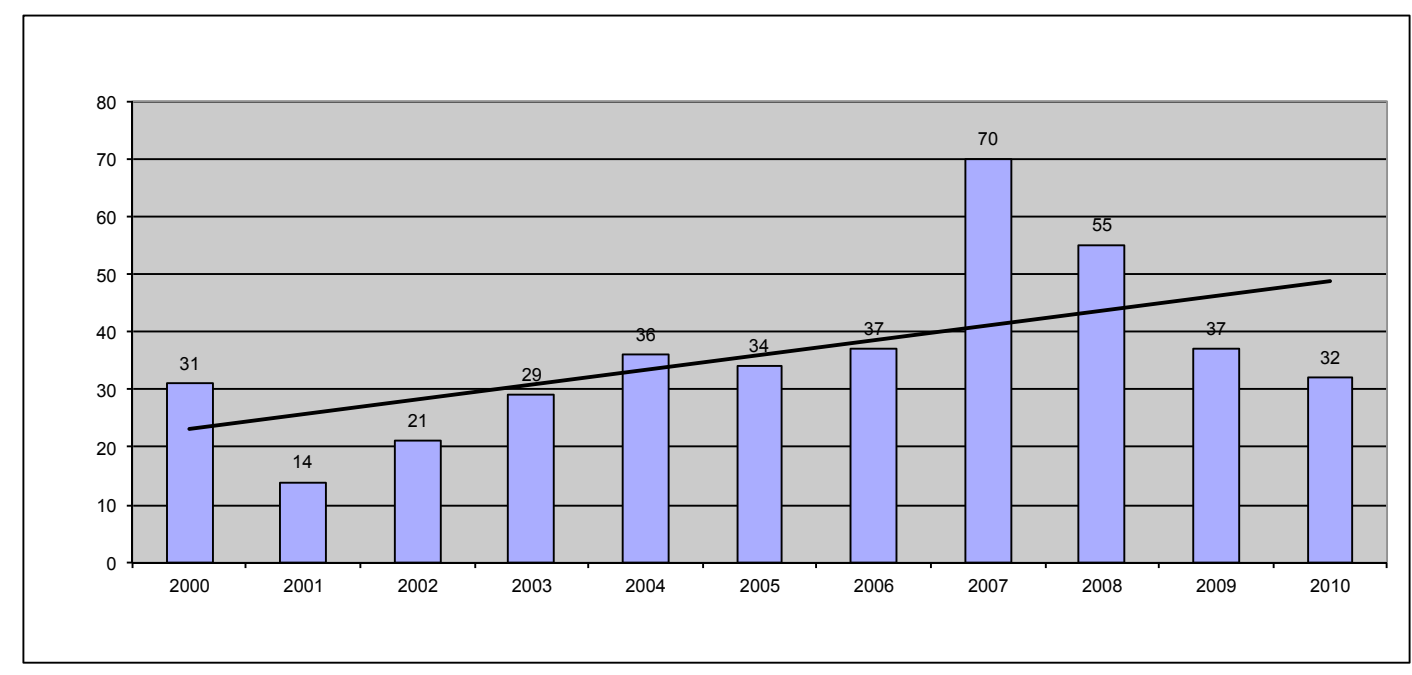

Graph I -Annual Brazilian Patent Applications in Representative Sectors of Biotechnology -2000 to 2010

ISSN: 07 I8-2724. (http://www.jotmi.org)

Journal of Technology Management \& Innovation @ Universidad Alberto Hurtado, Facultad de Economía y Negocios. 
d) Private firms: in this category were included only private companies, as isolated applicants without partnership;

e) Partnerships: this category was created to identify partnerships between public institutions and private firms, notably with universities, considering what Brazilian innovation law advocates. Although there are others forms of partnership between universities and private firms, such as consulting, spin-offs, and others agreements. In this article it is used the co-entitlement in patent applications as partnerships.

The largest patent applicant in Biotechnology are the universities, with 193 files in 10 years, followed by individuals with 78 files, research centers with 59 , private firms with 44 , and partnerships with 23 , according to Table 2 .

Although the universities hold $48 \%$ of the patent applications in Biotechnology, as indicated in Graph 2, it is worth noting that the number of applications by private firms is not so low when compared with public research centres, i.e. $11 \%$ and $15 \%$ of the total, respectively.

Since 2005 the number of patent applications filed by universities has been growing. This growth can be explained by implication of Innovation Law and also by INPI performance in the training of researchers of the Brazilian universities, and managers in charge of the Centers for Technological Innovation (NITs), established by the Innovation Law.
The amount of 3| Brazilian universities that have already filed patents in biotechnology in Brazil in the last decade are identified in Table 3. The five universities that have mostly filed were: São Paulo University (USP) with 35 patent applications, Minas Gerais University (UFMG) with 28, Campinas University (Unicamp) with 20, Rio de Janeiro University (UFRJ) with 19, and Brasilia University (UnB) with II, summing up I I 3 patent applications. Noted that of I9I patent applications filed by universities in 10 years, $59 \%$ were filed by these five universities.

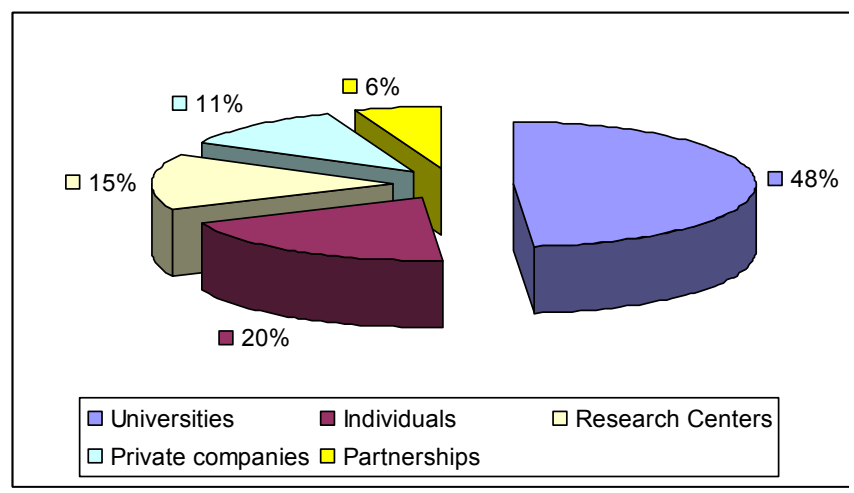

Graph 2: Brazilian Patent Applications distribution by applicants' profile in representatives sector of Biotechnology.

\begin{tabular}{|r|r|r|r|r|r|r|}
\hline Year & Universities & Individuals & Public Research Centers & Private Firms & Partnerships \\
\hline & & & & & & \\
\hline 2000 & 7 & 8 & 10 & 5 & 1 & 31 \\
\hline 2001 & 7 & 6 & 0 & 1 & 0 & 14 \\
\hline 2002 & 8 & 5 & 6 & 2 & 0 & 21 \\
\hline 2003 & 12 & 11 & 4 & 1 & 1 & 29 \\
\hline 2004 & 17 & 4 & 4 & 7 & 4 & 36 \\
\hline 2005 & 20 & 7 & 4 & 1 & 2 & 34 \\
\hline 2006 & 21 & 8 & 5 & 2 & 1 & 37 \\
\hline 2007 & 33 & 15 & 9 & 9 & 4 & 70 \\
\hline 2008 & 27 & 10 & 5 & 8 & 5 & 55 \\
\hline 2009 & 18 & 3 & 9 & 4 & 3 & 37 \\
\hline 2010 & 23 & 1 & 2 & 4 & 2 & 32 \\
\hline total & 193 & $\mathbf{7 8}$ & $\mathbf{5 8}$ & $\mathbf{4 4}$ & $\mathbf{2 3}$ & $\mathbf{3 9}$ \\
\hline
\end{tabular}

Table 2: Brazilian Patent Applications in Representative Sectors of Biotechnology by patent applicants' profile - 2000 to 2010.

ISSN: 07 I8-2724. (http://www.jotmi.org)

Journal of Technology Management \& Innovation (c) Universidad Alberto Hurtado, Facultad de Economía y Negocios. 


\begin{tabular}{|c|c|c|c|c|c|c|c|c|c|c|c|c|c|}
\hline & & 2000 & 2001 & 2002 & 2003 & 2004 & 2005 & 2006 & 2007 & 2008 & 2009 & 2010 & total \\
\hline 1 & $\begin{array}{l}\text { USP (São Paulo Uni- } \\
\text { versity) }\end{array}$ & 2 & & & 7 & 2 & 5 & 3 & 4 & 6 & 2 & 4 & 35 \\
\hline 2 & $\begin{array}{l}\text { UFMG (Minas Gerais } \\
\text { University) }\end{array}$ & 1 & 2 & 2 & & 1 & 1 & 1 & 9 & 6 & 2 & 3 & 28 \\
\hline 3 & $\begin{array}{l}\text { UNICAMP (Campinas } \\
\text { University) }\end{array}$ & 2 & 1 & 2 & 1 & 2 & 4 & & 2 & 1 & 3 & 2 & 20 \\
\hline 4 & $\begin{array}{l}\text { UFRJ (Rio de Janeiro } \\
\text { University) }\end{array}$ & & 1 & & 1 & 4 & 1 & 3 & 5 & 2 & & 2 & 19 \\
\hline 5 & $\begin{array}{l}\text { UnB (Brasilia Univer- } \\
\text { sity) }\end{array}$ & & 1 & & 1 & & 2 & 2 & 3 & 2 & & & 11 \\
\hline 6 & $\begin{array}{l}\text { UFRGS (Rio Grande } \\
\text { do Sul University) }\end{array}$ & 1 & & & & 3 & & & & & 4 & 2 & 10 \\
\hline 7 & $\begin{array}{l}\text { UNESP (São Paulo } \\
\text { Estadual University) }\end{array}$ & & 1 & 2 & 1 & & 1 & & 1 & 1 & & 1 & 8 \\
\hline 8 & $\begin{array}{l}\text { UCS (Caxias do Sul } \\
\text { University) }\end{array}$ & & & & & & & 1 & 3 & 3 & 1 & & 8 \\
\hline 9 & $\begin{array}{l}\text { UFV (Viçosa Univer- } \\
\text { sity) }\end{array}$ & 1 & & & & & 1 & 1 & 1 & & & 2 & 6 \\
\hline 10 & $\begin{array}{l}\text { UNIFESP (São Paulo } \\
\text { University) }\end{array}$ & & & 1 & & 1 & & 2 & 1 & & & & 5 \\
\hline 11 & $\begin{array}{l}\text { UFOP (Ouro Preto/ } \\
\text { Minas Gerais Univer- } \\
\text { sity) }\end{array}$ & & 1 & & 1 & 2 & & 1 & & & & & 5 \\
\hline 12 & $\begin{array}{l}\text { UFsCAR ( São } \\
\text { Carlos/ São Paulo } \\
\text { University) }\end{array}$ & & & 1 & & & & 1 & 2 & & 1 & & 5 \\
\hline 13 & $\begin{array}{l}\text { UFPR ( Paraná Uni- } \\
\text { versity) }\end{array}$ & & & & & & & & 1 & 2 & & 2 & 5 \\
\hline 14 & $\begin{array}{l}\text { UFU (Uberlândia/ } \\
\text { Minas Gerais Univer- } \\
\text { sity) }\end{array}$ & & & & & 1 & & & & & 1 & 2 & 4 \\
\hline 15 & $\begin{array}{l}\text { PUC (Católica do } \\
\text { Rio Grande do Sul } \\
\text { University) }\end{array}$ & & & & & & 1 & & 1 & 1 & & & 3 \\
\hline 16 & $\begin{array}{l}\text { UFPEL (Pelotas/ Rio } \\
\text { Grande do Sul Uni- } \\
\text { versity) }\end{array}$ & & & & & 1 & & 1 & & & & & 2 \\
\hline 17 & $\begin{array}{l}\text { UENF (Norte Flumin- } \\
\text { ense Estadual do Rio } \\
\text { de Janeiro University)) }\end{array}$ & & & & & & 1 & & & & 1 & & 2 \\
\hline 18 & $\begin{array}{l}\text { UFSC ( Santa Catari- } \\
\text { na University) }\end{array}$ & & & & & & & & & 1 & 1 & & 2 \\
\hline
\end{tabular}

ISSN: 07 I8-2724. (http://www.jotmi.org)

Journal of Technology Management \& Innovation @ Universidad Alberto Hurtado, Facultad de Economía y Negocios. 


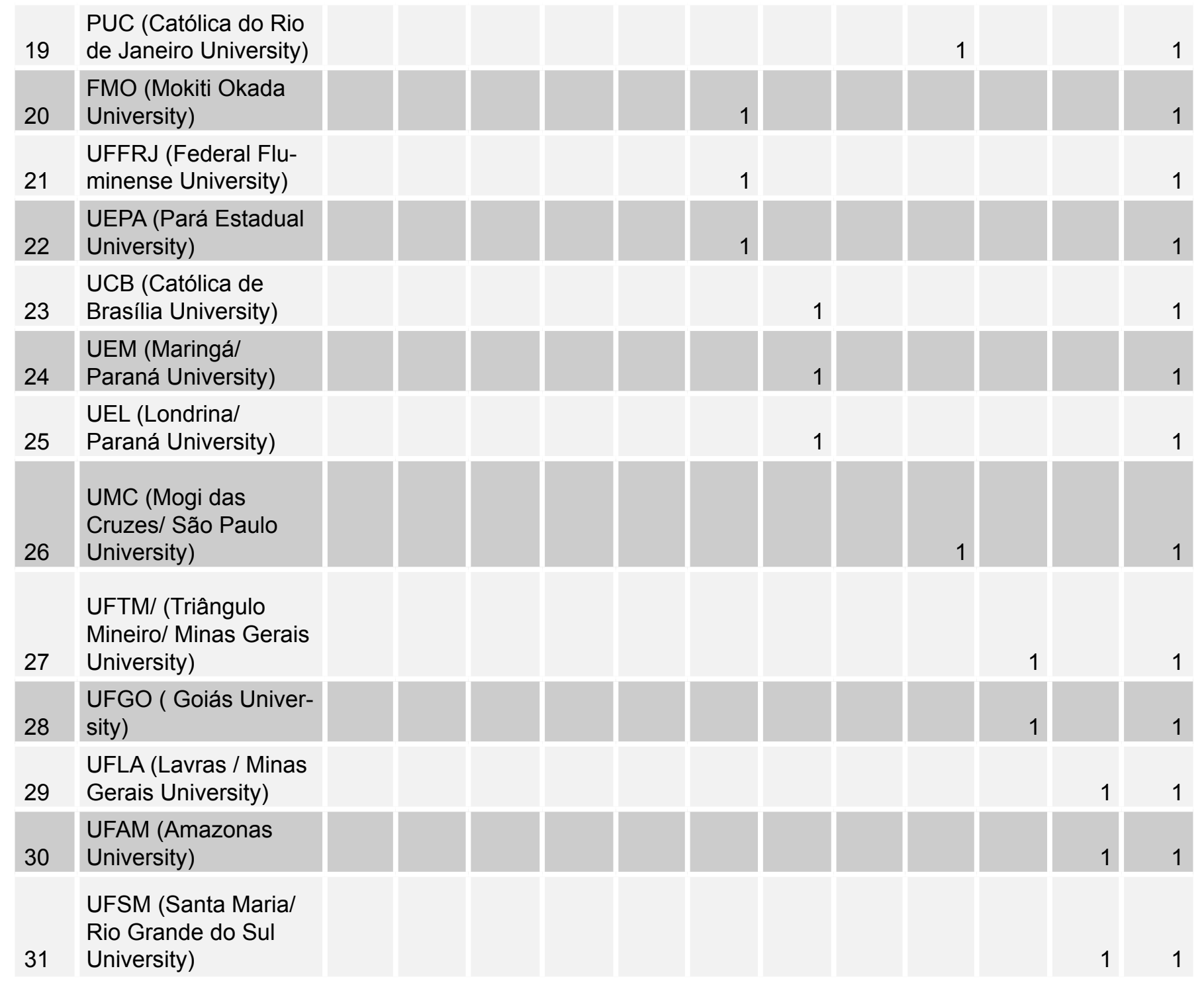

Table 3: Number of Annual Brazilian Patent Applications by Brazilian Universities in representative sectors of Biotechnology - 2000 to 2010. 
On the other hand, it can be observed in Figure 2 that the partnerships between universities and private firms are still not significant. In the last 10 years, of the total of 23 partnerships in patent applications between public institutions and private firms, 13 were with Brazilian universities, 4 with São Paulo University, and 4 with Brasilia University. All of then with different private firms. In addition, I 2 partnerships were established since the entry into force of Innovation Law in 2005.

\section{Partnerships in Patent Applications}

There are only two private firms which have more than one patent application in partnerships with universities - Biolab Sanus and Farmarcor Biotec, but none of them have more than two patent application each one.

\begin{tabular}{|c|c|c|c|}
\hline \multicolumn{4}{|c|}{ Partnerships in Patent Applications } \\
\hline Year & Public research center & Universities & Private firms \\
\hline 2000 & $\begin{array}{l}\text { Brazilian Agrobusiness } \\
\text { Company (EMBRAPA) }\end{array}$ & & VALEE S.A. \\
\hline 2003 & $\begin{array}{l}\text { Research Founda- } \\
\text { tion of Minas Gerais } \\
\text { (FAPEMIG) }\end{array}$ & & BIOGENETICS \\
\hline 2004 & $\begin{array}{c}\text { Brazilian Nuclear Energy } \\
\text { Commission (CNEN) }\end{array}$ & & HORMOGEN \\
\hline 2004 & $\begin{array}{l}\text { Research Foundation of } \\
\text { São Paulo (FAPESP) }\end{array}$ & & BIOLAB SANUS \\
\hline 2004 & $\begin{array}{l}\text { Research Foundation of } \\
\text { São Paulo (FAPESP) }\end{array}$ & & BIOSINTÉTICA LTDA \\
\hline 2004 & & UNIFESP & UNIÃO QUÍMICA \\
\hline 2005 & BUTANTAN Institute & & BIOLAB SANUS \\
\hline 2005 & & UNIVERSIDADE DE BRASILIA & POLI ENGENHARIA \\
\hline 2006 & $\begin{array}{l}\text { Research Foundation of } \\
\text { São Paulo (FAPESP) }\end{array}$ & & CRISTÁLIA \\
\hline 2007 & & UNIVERSIDADE DE SÃO PAULO & FARMARCOR BIOTEC \\
\hline 2007 & & UNIVERSIDADE DE SÃO PAULO & FARMARCOR BIOTEC \\
\hline 2007 & & CAIXIAS DO SUL & BIOENZIMA \\
\hline 2007 & & UNIVERSIDADE DE SÃO PAULO & BIOVEGETAL \\
\hline 2008 & & UNIVERSIDADE DE BRASILIA & OURO FINO \\
\hline 2008 & SENAI & & BIOTECNOLOGIA S.A. \\
\hline 2008 & & UNICAMP & BLAUSIGEL \\
\hline 2008 & & UNIVERSIDADE DE BRASILIA & COALHOS BIO PARAN \\
\hline 2008 & & UBERLÂNDIA & IMUNOSCAN MOLECULAR \\
\hline 2009 & & SANTA CATARINA & MEDIC FORMULA \\
\hline 2009 & & UNIVERSIDADE DE BRASILIA & UNICÓRNIO REPROD. ANIMAL \\
\hline 2009 & BUTANTAN Institute & & HOSPITAL ALEMÃO \\
\hline 2010 & $\begin{array}{l}\text { Oswaldo Cruz Founda- } \\
\text { tion (FIOCRUZ) }\end{array}$ & & ALVOS CONSULT. PROD. BIOTEC \\
\hline 2010 & & UNIVERSIDADE DE SÃO PAULO & INVENT. BIOTEC \\
\hline
\end{tabular}

Figure 2: Partnerships in patent applications from 2000 to 2010

ISSN: 07 I8-2724. (http://www.jotmi.org) 


\section{Final Remarks}

The handling of the compiled information will enable the development of an insertion mapping of the IP topic in postgraduate courses in biotechnology and Brazilian universities. Later it will be possible to make a comparative analysis with data from other countries. But it is worth noting that the patent applications in the USA and China, for example, have already reached the thousands by year. While in Brazil the amount of residents patent applications in representatives sectors of Biotechnology does not reach 400 applications in 10 years.

It will also be possible to conduct an analysis of the content of the patents filed in Biotechnology aiming the identification of the technological fields that are being investigated by Brazilian inventors. Beforehand, we can identify genetic engineering as the field that assembles the majority of patent applications.

Among the different patent applicants profile, two groups draw attention, "universities" that had a significant growth over the decade, and "inventors" with a clear decrease compared to the beginning of the last decade. These outcomes are interesting, mainly if one takes into account that Brazilian universities has been increasing more and more their research capacity, which could mean better patents, technically. However the two groups mentioned, do not act directly in the market, depending on the transfer of technology to firms that actually have access to the market.

Another aspect to point out is that since 2005 the number of patent applications filed by universities has been growing. This growth can be explained by the implementation of the Innovation Law and also by the INPI performance in the process of the managers' training and the dissemination of Intellectual Property culture, beyond others institutional aspects.

Further studies of the compiled data, and more research on scientific publication, and also in the academic IP teaching will enable depth analysis, that may help clarify the gap between scientific production and innovation in the biotechnology academic environment. It will also allow a better understanding of the global context where the national and international debate on the topics of IP and biotechnology is inserted, and provide elements on how to adjust to this context to respond for a emerging IP agenda, that can assist in public policies formulation in this field.

\section{References}

AGÊNCIA Gestão Ciência, Tecnologia \& Inovação (20I3)."Falta ao Brasil trilhar um caminho entre as empresas e universidades, afirma ministro". http://www.agenciacti. com.br/index.php?option=com_content\&view=article\&id= 24|8:falta-ao-brasil-trilhar-um-caminho-entre-as-empresase-universidades-afirma-ministro\&catid=1:latest-news [Accessed March 16th, 2013]

BRASIL (1996). Law n 9.279 March 14, 1996. Lei da Propriedade Industrial. Regula direitos e obrigações relativos à propriedade industrial. Diário Oficial da União, Brasília, DF.

BRASIL (2004). Law $n^{\circ} 10.973$, December 2, 2004. Lei de Inovação. Dispõe sobre incentivos à inovação e à pesquisa científica e tecnológica no ambiente produtivo e dá outras providências. Diário Oficial da União, Brasília, DF.

CRUZ, C.H., Pacheco, C.A. (2004). Conhecimento e Inovação: Desafios do Brasil no Século XXI.

http://www.inovacao.unicamp.br/report/inte-pacheco-brito. pdf [Accessed June 28th, 20I3]

GLOBAL Innovation Index (20I2). Stronger Innovation Linkages For Global Growth. World Intellectual Property Organization (WIPO) and Insead. http://www.globalinnovationindex.org/gii/main/fullreport/index.html [Accessed March 30th, 20I3]

GULLO, L.M., Guerrante, R.S., Mendes, C.S. M. (20II). Principais titulares de pedidos de patentes no Brasil, com prioridade brasileira - depositados no período de 2004 a 2008, Instituto Nacional da Propriedade Industrial, Centro de Documentação e Informação Tecnológica.

htpp://www.inpi.gov.br/images/stories/download/patentes/ pdf/Principais_Titulares_julho_20I I.pdf

[Accessed April 16th, 2013]

JANNUZZI, A.H.L. Souza, C.G. (2008). Patentes de invenção e artigos científicos: especificidades e similitudes. Revista Brasileira de Pós-Graduação, 5 (9), I03-125.

LUNDVALL, B. (2005). National Innovation Systems - Analytical Concept and Development Tool. Tenth Anniversary Summer Conference on Dynamics of Industry and Innovation: Organizations, Networks and Systems, Copenhagen. http://www.druid.dk/wp/pdf_files/96-I.pdf. [Accessed March I5th, 2013]

MANUAL de Oslo (1997). http://www.finep.gov.br/imprensa/sala_imprensa/manual_ de_oslo.pdf. [Accessed March 15th, 2013] 
NATURE (2010). "Brazil's biotech boom". Nature Journal, 466 (7304).

ORGANISATION for Economic Co-operation and Development - OECD (2005). A Framework for Biotechnology Statistics. http://www.oecd.org/sti/sci-tech/34935605.pdf [Accessed July 28th, 20I3]

OLIVEIRA, R.M.,Velho, L.M.L.S. (2009). Patentes acadêmicas no Brasil: uma análise sobre as universidades públicas paulistas e seus inventores. Parcerias Estratégicas, 14, 173-200.

PAVITT, K. (1990). Sectorial patterns of technical changes: Towards a taxonomy and a theory. The Economics of Innovation. Edward Elgar Publishing Ltd., United Kingdom. http:// dx.doi.org/I0.1016/0048-7333(84)90018-0

PÓVOA, L.M.C. (2006). Depósito de Patentes de Universidades Brasileiras (1976 - 2004). Anais do XII Seminário sobre Economia Mineira, Diamantina. htpp://www.cedeplar. ufmg.Br/seminários/seminário_diamantina/2006/D06A006. pdf [Accessed April 16th, 2 013]

QUERIDO, A.L.S., Lage, C. L. S., Vasconcellos, A. G. (20I2). What is the destiny of Patents of Brazilian Universities. Journal of Technology Management \& Innovation, 6 (I), 47-57. http://dx.doi.org/I0.4067/S07/8-272420I I000I00005

RAPINI, M.S. (2007). Interação Universidade-Empresa no Brasil: Evidências do Diretório dos Grupos de Pesquisa do CNPq. Estudos Econômicos. São Paulo, 37( I), 2 I I-233.

SANTOS, E. (2010). Estudo do uso de literatura não patenteada, no exame de patente da área de biotecnologia, no Instituto Nacional da Propriedade Industrial do Brasil. Dissertação de Mestrado em Propriedade Intelectual e Inovação. Instituto Nacional da Propriedade Industrial, Rio de Janeiro.

SOUZA, C.G., Barbastefano, R.G., Pereira, F. C. (20II). Estudo sobre perfil dos inventores das patentes de universidades brasileiras. XXXI Encontro Nacional de Engenharia de Produção, Belo Horizonte. htpp://wwwabepro.org.br/ biblioteca/energep20II_TN_STO_I42_896_I8859.pdf [Accessed April 16th, 2 013]

VASCONCELLOS,A. G. (2003). Propriedade intelectual dos conhecimentos associados à biodiversidade, com ênfase nos derivados de plantas medicinais - desafio para inovação biotecnológica no Brasil. Tese de Doutorado em Biotecnologia Vegetal. Universidade Federal do Rio de Janeiro - UFRJ, Rio de Janeiro. 